This is an author-produced PDF of an article accepted for publication in The Asia Pacific Journal of Anthropology. The definitive publisher-authenticated version is available online. Copyright The Asia Pacific Journal of Anthropology. Complete citation information of that definitive version is: Grant, C. (2013). Drums on the Red River [DVD review]. The Asia Pacific Journal of Anthropology 14(3), 291292. doi: $10.1080 / 14442213.2013 .787907$

\title{
Drums on the Red River
}

LAN PHUONG, JAYASINHJI JHALA, HOANG SON, and LAUREN MEEKER

Vietnam Institute of Culture and Arts Studies, Temple University [Producer]

Watertown, MA, DER Educational Resources, 2010

DVD, colour, 73 mins, US\$195 (institutional sale) / US\$39.95 (home use sale)

Every year from the tenth to the twelfth day of the second lunar month, the Chử Đồng Tử Festival is held by the banks of the Red River in Hưng Yên Province, Vietnam. This jubilant and popular event celebrates Chử Đồng Tử, one of four "immortal heroes" of the Vietnamese people. The video documentary Drums on the Red River centres around the festivities as they take place at Chử Đồng Tử Temple in Bình Minh commune, Khoái Châu District, around 40 kilometres south-east of Hànội. Specifically, it traces the colourful processions, ceremonies, ritual offerings, feasting, dancing, and traditional games that made up the three days of the 2007 festival (28-30 March).

The film begins by recounting, in the words of participants in the 2007 festival, the story of Chử Đồng Tử, who is said to have developed agriculture and trade and discovered culture in Vietnamese society. Elders from participating villages clarify the symbolic relevance to the festival of various aspects of Chử Đồng Tử Temple itself - monuments, stele, bells, stone dragons, pavilions, altars, and statues. They also make tantalisingly brief reference to their perspectives on the political positioning of the festival in modern Vietnam, including the contemporary relevance to the festivities of "Uncle Hồ" (Hồ Chí Minh) and the revolution.

The remaining 50 or so minutes of the film documents the festival preparations, the opening procession and ceremony, the elaborate rituals on the Red River, convergence back on Chử Đồng Tử Temple, traditional games that follow, and the immediate aftermath of the festival. The celebratory nature of the entire event is perhaps most palpable in the scenes of the outdoor games and activities that take place towards the end of the festivities, from dancing, wrestling, cock fights, and golden dancing dragons to traditional quan ho singing and human chess in the temple yard.

A particularly striking section of the documentary is the depiction of the water procession on the Red River that takes place on the second day of the festival. The procession invokes the legendary river journey of the beautiful Princess Tiên Dung, during which she first encounters the poor fisherman Chử Đồng Tử - later to become the princess's immortal husband - as he hides naked in reeds along the banks. A flotilla of boats makes its way to the centre of the Red River, where elders of the participating villages conduct an elaborate ritual in which river water is scooped 
into porcelain jars. The water is later returned in procession to the temple, where it is used for ritual purposes throughout the year.

The documentary alludes to a number of changes to the festival, both minor and more significant, in recent years. Only two or three years ago, for example, the red drums referred to in the documentary's title were played by “elderly men in tunics with white belts, a turban, and in hierarchical order;" drummers now include pre-pubescent boys. Villagers also comment on a greatly reduced amount of time taken to reach the main temple in procession, a reduction in the number of villages participating in the festival, and key shifts in gender roles and practices. Certain stable aspects of the tradition are considered worthy of comment (for example: "about the dragon, we have kept the same tradition as our ancestors").

Drums on the Red River is satisfying to watch. Subtitles are lucid (notwithstanding the occasional misspelt word), sound quality is generally good, and the visual element is striking. The film presents the Chử Đồng Tử Festival entirely in the words of the villagers and (mostly elderly) participants, rendering it both authoritative and respectful. A diversity of local perspectives are directly represented in the film, including those of a commune chairman (49 years old), a female member of a village organising board (60), and around a dozen villagers, most in their 70s and 80s, but including some teenagers too.

The grandeur and spectacle of the Chử Đồng Tử Festival in itself would make for an engaging documentary; it certainly attracts its fair share of tourists in the flesh, who travel downstream on the Red River by boat (or if adventurous, make their way to the event by motorbike). But aside from the festivities themselves, an added element of interest for the ethnomusicologists is likely to be the sociocultural, economic, and political context of the festival in contemporary Vietnam. Following a period of several decades during which many Vietnamese traditional cultural expressions were repressed or banned altogether, their revitalisation came (in many cases) with the change of governmental attitude to Vietnamese traditional culture that followed economic reform of the late 1980s. In this way, the Chử Đồng Tử Festival is representative of a wider revival of traditional practices in contemporary Vietnam. This topic is little addressed in the film, leaving the viewer wanting more. Nevertheless, the DVD remains highly recommended for its engaging and sensitive documentation of this cultural event.

The first 7 minutes of the film is available for preview at http://www.der.org/films/drums-onthe-red-river.html, but is unfortunately barely indicative of the character or colour of the documentary as a whole.

CATHERINE GRANT 